\title{
Impacts of the North Atlantic Oscillation on the probability of dry and wet winters in Spain
}

\author{
D. Muñoz-Díaz, F. S. Rodrigo* \\ Department of Applied Physics, University of Almería, La Cañada de San Urbano s/n, 04120 Almería, Spain
}

\begin{abstract}
In many regions of the world, agricultural and water management is usually based on probabilities of seasonal or monthly rainfall, commonly grouped into 3 categories: drought, normal rainfall, and abundant rainfall. Changes in the probabilities of the occurrence of rainfall amounts within these climatic rainfall categories will influence decision-making by farmers and water managers. This study explores the changes induced by the North Atlantic Oscillation (NAO) on the probability of winter rainfall in Spain. The evolution of the NAO was divided into 3 phases: negative NAO (NAO-), neutral NAO (NAOn), and positive NAO (NAO+), and rainfall series were divided into 3 groups corresponding to each NAO phase. Resulting empirical distribution functions allow an estimate of the changes in the probabilities of wet and dry winters due to changes in the NAO phase. Changes in the probability of the occurrence of the rainfall categories are more complex than mere increases in rainfall amount during NAO- and decreases during NAO+ phase. The spatial distribution of impacts is asymmetric, with higher probability of extremes linked to NAO- in the western area of the Iberian Peninsula.
\end{abstract}

KEY WORDS: North Atlantic Oscillation · Rainfall $\cdot$ Spain

Resale or republication not permitted without written consent of the publisher

\section{INTRODUCTION}

The North Atlantic Oscillation (NAO) is one of the most important modes of low-frequency variability in geopotential heights in the northern hemisphere (Barnston \& Livezey 1987). Most studies of the NAO focus on the winter months, when the atmosphere is most active dynamically and perturbations grow to their largest amplitudes. As a result, the influence of the NAO on surface temperature and precipitation, as well as on ecosystems, is also greatest at this time of the year (Hurrell et al. 2003). The NAO is characterized by a north-south dipolar pattern in sea-level pressure, with one of the centers located over Iceland and the other approximately over the Azores. This dipolar pattern reflects the strong contrast in meridional pressure over the North Atlantic region. The positive phase of the NAO reflects below-normal heights and pressure across the high latitudes of the North Atlantic, and above-normal heights and pressure over the central North Atlantic. The negative phase is characterized by anomalies that are opposite to those observed during the positive phase. Both phases of the NAO are associated with basin-wide changes in the intensity and location of the North Atlantic jet stream and storm tracks, and with changes in the patterns of zonal and meridional heat and moisture transport from the Atlantic Ocean to the continental areas of Europe. A northward shift in the axis of maximum moisture transport is observed when the NAO is in the positive phase (Hurrell 1995). This results in an intensified westerly flow that brings warm maritime air to Europe, reducing the polar outbreaks over Europe and leading to a warming of central and southern Europe and a cooling of the NW Atlantic area (Rogers \& van Loon 1979).

One technique for monitoring the NAO and studying its temporal variability in time is by means of an index. This index is constructed using the pressure differences between a station located near the southern centre of the dipole and another one near the northern centre. Several NAO indices have been proposed recently, using different stations and different timeaveraged intervals of the year (Hurrell \& van Loon 1997, Jones et al. 1997, 2003). 
Several studies have focused on the relationship between large-scale pressure fields, such as the NAO, and European climate, e.g. with regard to rainfall in the United Kingdom and Ireland (Murphy \& Washington 2001, Fowler \& Kilsby 2002), temperature series in the Czech Republic (Bodri \& Cermak 2003) and Hungary (Matyasovszky 2003), or winter precipitation in northern Europe (Uvo 2003). The changes in atmospheric circulation over the Atlantic are connected with pronounced regional changes in precipitation patterns (Hurrell 1995, Hurrell \& van Loon 1997, Dai et al. 1998). The association between fluctuations in the NAO and rainfall in the Iberian Peninsula and northern Africa has been the subject of various studies: Rodó et al. (1977) found a strong relationship between NAO and winter rainfall in the western part of the Iberian Peninsula; Lamb \& Peppler (1987) found a strong inverse relationship between precipitation in northern Morocco and the NAO (correlation of -0.64 for the period October-April); Zorita et al. (1992) found a correlation of -0.5 between the NAO index and precipitation in the SW Iberian Peninsula in winter; Esteban-Parra et al. (1998) calculated the correlation coefficients between the NAO index computed by Hurrell (1995) and precipitation series in Spain: their results, significant at the $95 \%$ confidence level, were -0.55 for annual rainfall and -0.67 for winter rainfall; Ulbrich et al. (1999) confirmed the importance of the NAO for the variability of rainfall in Portugal; Goodess \& Jones (2002) found significant negative correlations between NAO and rainfall at 18 Iberian stations; Knippertz et al. (2003) analyzed the long-term variability of precipitation in Morocco and its link to the large-scale circulation, finding a correlation coefficient of -0.71 with NAO in winter. A physical rationale for the inverse relationship between NAO and rainfall was given by Hurrell \& van Loon (1997), Corte Real et al. (1998), Ulbrich et al. (1999) and Trigo et al. (2002): high index values are associated with stronger westerlies, driven in part by an intensification of high pressure in the western Iberian Peninsula, producing blocking situations over the study area. In contrast, low index values and intensified meridional circulation, shift the Atlantic cyclones southward, so that these invade the Iberian Peninsula. Therefore, high NAO index values are related to low annual and seasonal precipitation (drought), and low index values are related to intense rainfall and floods.

Because of its dominant impact on the weather and climate of Europe, there is a growing interest in quantifying the possible limits of seasonal and interannual predictability of the NAO. Predictability studies have identified only limited NAO skill to date. Baldwin et al. (2003) used a linear model to predict the monthly mean Artic Oscillation from stratosphere-troposphere coupling. Saunders et al. (2003) examined the seasonal predictability of the winter NAO from the lagged extension of northern hemisphere snow cover. According to these authors, wintertime NAO is predictable from North Hemisphere snow cover with a correlation skill of approximately 0.6. Most efforts have focused on the role of lagged North Atlantic sea surface temperatures (SST) (Rodwell \& Folland 2001). Around 15\% of the variance in seasonal mean surface level pressure is due to forcing from SST, with May as the best month to make such a prediction (predictive skill correlation of around 0.45) (Rodwell 2003).

If the NAO can be forecast using SST or other variables, then we may estimate the winter rainfall regime a few months in advance, and this is important for hydrological planning and management. The use of the NAO for predicting effects on economic activities is of great interest (Mysterud et al 2003); for instance, Wilby (2001) used NAO to forecast river flows on the British Isles; Rîmbu et al. (2002) studied the relationship between decadal variability of Danube River flow and the NAO; Rodó \& Comín (2000) studied the relationship to wine quality in Spain; Esteves \& Orgaz (2001) indicated that there is a negative relationship between the NAO in April and wine quality in Portugal, and Kettlewell et al. $(1999,2003)$ showed that wheat grown in the United Kingdom is strongly related to the North Atlantic Oscillation in the preceding winter.

Many agricultural and water management activities are planned on the basis of monthly and seasonal rainfall categories. The main objective of this study was to identify whether a given phase of the NAO increases or decreases the probability of 3 seasonal rainfall categories: drought, normal or abundant. The rainfall categories were determined according to the percentile values of rainfall distribution during a reference period. This study is the extension of a previous one (Muñoz-Díaz \& Rodrigo 2003) focused on the effects of NAO on monthly rainfall of 10 stations in the southern Iberian Peninsula. Here, we analyze 32 rain gauges covering the whole country, for the period 1912-2000; the time scale is seasonal instead of monthly, because seasonal time resolution is commonly used in climate prediction and in planning and management studies. The winter NAO index was preferred over other variables such as SST for seasonal forecasting, because it is straightforward to compute, readily available and regularly updated (Wilby 2001).

\section{DATA}

\subsection{Winter NAO index}

A monthly index representative of the North Atlantic Oscillation, developed by Jones et al. (1997), has been used for this study. The index was formulated using 
data from Gibraltar $\left(36.1^{\circ} \mathrm{N}, 5.4^{\circ} \mathrm{W}\right)$ and south Iceland, mainly from Reykjavik $\left(64.1^{\circ} \mathrm{N}, 22.5^{\circ} \mathrm{W}\right)$, for 1826-2000 (data available at www.cru.uea.ac.uk). Gibraltar appears to better represent the southern part of the NAO dipole during winter than other commonly used stations, such as Lisbon, or Ponta Delgada on the Azores (Jones et al. 1997, Pozo-Vázquez et al. 2000). A normalization procedure for each pressure time series is necessary to prevent the index from being biased and misleading, owing to different statistical characteristics of pressure data from the northern and southern stations (especially regarding $\mathrm{SD}$ ), and owing to the change of both mean and SD throughout the year. Thus a monthly deseasonalized and normalized index was constructed for each station, by calculating the difference between each raw monthly value and a time-averaged mean value, and then dividing by a time-averaged monthly SD. Normalization was for the period 1961-1990, following WMO suggestions to establish a $30 \mathrm{yr}$ period for the definition of climate normals (Ojo \& Afiesimama 2000), and to take into account that future projections on climate change (e.g. Hulme \& Sheard 1999) use this period as reference and express future climate changes as percentages of this period's values. The monthly NAO index was obtained as the difference between the normalized values of pressure in Gibraltar and Iceland. Monthly data were averaged to obtain a seasonal index. The correlation coefficient between this index and that based on Azores pressure data is 0.87 (significant at a 95\% confidence level) for 1865-2000. The NAO index obtained is $I=0.39 \pm 1.23(\mathrm{SD})$ (deviating from $I=0 \pm 1$, due to the normalization period selected). The standard skewness and kurtosis coefficients are -0.92 and -1.92 , respectively; this is within the range expected for data from a normal distribution. The fact that the NAO index may deviate significantly from normality may have important implications for NAO forecasting and can easily give the impression of non-stationary in time series (Burgers \& Stephenson 1999). We analyzed the normality of the NAO Index by applying a Kolmogorov-Smirnov (KS) test:

$$
D=\max \left\{\left|Q_{\mathrm{i}}-P_{\mathrm{i}}\right|\right\}_{;} \quad \mathrm{i}=1, \ldots, \mathrm{n}
$$

where $D$ is the KS test statistic, $Q_{\mathrm{i}}$ is the cumulative empirical distribution, $P_{\mathrm{i}}$ is the theoretical distribution to be tested, and $\mathrm{n}$ is the number of observations. If $D \leq$ $(1.36 / \sqrt{ } \mathrm{n})$, with a sufficiently large number of observations, the hypothesis is accepted with a confidence level of $95 \%$ (Peña-Sánchez 1995). The result was $\mathrm{D}=0.0395<(1.36 / \sqrt{ } \mathrm{n})$, therefore there is not enough evidence to prove that the distribution is not normal.

A $t$-test was carried out and the $95 \%$ confidence interval of the mean was $(0.22,0.55)$. Therefore, the null hypothesis that the mean equals zero must be

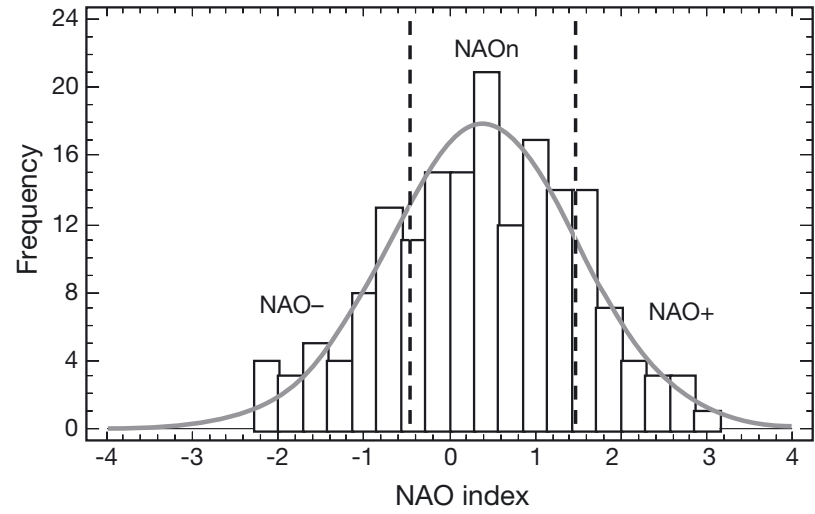

Fig. 1. Histrogram of the NAO index for the period 1826-1999, Gaussian distribution fitted, and threshold values (vertical dashed lines) used to define the 3 NAO phases

rejected. If we accept the Gaussian character of the index, this circumstance allows us to establish the symmetry of the index values around the mean value. In this study, the evolution of the NAO was divided into 3 phases: (1) negative NAO (NAO-) when $I<\bar{I}-1$, where $\bar{I}$ is the mean value of the index; (2) neutral NAO (NAOn) when $\bar{I}-1 \leq I \leq \bar{I}+1$; and (3) positive NAO (NAO+) when $I>\bar{I}+1$. In this way, the extreme NAO phases are expressed as deviations $>1 \mathrm{SD}$ in the reference period 1961-1990. Note that using this methodology, the threshold values to define extreme phases of the NAO index $\left(-0.61\right.$ for $\mathrm{NAO}_{-},+1.39$ for $\mathrm{NAO}+$ ) differ from \pm 1 . Fig. 1 shows the histogram of the NAO index for 1826-1999, the Gaussian distribution fitted, and the threshold values obtained to define the 3 NAO phases. This methodology is similar to that used by Beniston \& Jungo (2002) to define extreme NAO phases, using as threshold values the percentiles $10 \%$ and $90 \%$ of the NAO index.

The percentages of data falling within each phase are the following: NAO- $19 \%$, NAOn $63 \%$, NAO+ $18 \%$. Table 1 shows the basic statistics for each NAO phase during 1912-2000, and the overall values for 1826-2000. The mean of NAO+ is +1.83 and that of NAO- is -1.37 . These values are representative of 2 highly contrasting synoptic regimes, namely above-average pressure over the Iberian Peninsula associated with negative rainfall anomalies, and lower than average pressure and strong rainfalls, respectively. The mean

Table 1. Mean value of the NAO indices $(\bar{I} \pm \mathrm{SD})$ for each phase during 1912-2000, and overall for the period 1826-1999

\begin{tabular}{|lccc|}
\hline $\mathrm{NAO}+$ & $\mathrm{NAOn}$ & $\mathrm{NAO}-$ & $1826-1999$ \\
\hline$+1.83 \pm 0.39$ & $+0.39 \pm 0.39$ & $-1.37 \pm 0.56$ & $+0.39 \pm 1.23$ \\
\hline
\end{tabular}


value corresponding to NAOn is equal to that of the period 1826-2000. On the other hand, SD is equal for $\mathrm{NAO}+$ and NAOn, and slightly higher for NAO-. A possible explanation is that in the NAO- mode the pressure distribution is not necessarily reversed, since there is still an Icelandic Low and an Azores High; the differences in pressure are weaker than normal, however, as complete reversals with higher pressure over Iceland than over the Azores occur very rarely (Wanner et al 2001). Therefore, higher variability in NAO- is expected.

\subsection{Rainfall series in Spain}

The database used in this study comprises total winter rainfall (December, January, February) at 32 Spanish localities, covering the Iberian Peninsula except Portugal. Fig. 2 shows the locations of the rain gauges and Table 2 shows the geographical data, mean and SD of winter rainfall at the stations. They were selected from a list of rain gauges supplied by the Spanish Institute of Meteorology (INM). Most of the stations have not changed their position, but the metadata relative to methods and instruments is known for only a few. Almarza et al. (1996) and Esteban-Parra et al. (1998) analyzed the homogeneity of these series applying absolute homogeneity tests (Thom and Mann-Kendall tests) and relative homogeneity tests (Barlett and Alexanderson tests), and they concluded that these series are high quality and do not present inhomogeneity problems. The data for 13 rain gauges have no gaps, and for the other rain gauges missing data are less than $5 \%$. In these cases, corresponding monthly mean value substituted the missing values. The period 1912-2000, common for all meteorological stations, was selected for this study. Meteorological stations are located at longitudes from $2^{\circ} 04^{\prime} \mathrm{E}$ (Barcelona) to $8^{\circ} 26^{\prime} \mathrm{W}$ (Santiago de Compostela) and latitudes from $43^{\circ} 27^{\prime} \mathrm{N}$ (Santander) to $36^{\circ} 27^{\prime} \mathrm{N}$ (San Fernando), and at altitudes above sea level (a.s.l.) ranging from $6 \mathrm{~m}$ a.s.l. (Barcelona) to $1080 \mathrm{~m}$ a.s.l. (Soria). Winter mean rainfall range from a maximum of $631.1 \mathrm{~mm}$ in the NW (Santiago de Compostela) to minimum values of $64.5 \mathrm{~mm}$ in the east (Zaragoza) and $68.6 \mathrm{~mm}$ in the SE (Murcia). To avoid masking of the results by different geographical conditions and to eliminate possible scale effects, the variables were standardized, using again the period 1961-1990 as reference

$$
z_{i}(t)=\frac{x_{i}(t)-\overline{x_{i}}}{\sigma_{i}}
$$

where $\mathrm{z}_{i}(t)$ is winter rainfall anomaly at station $i$ in year $t, x_{i}(t)$ is winter rainfall at station $i$ in year $t$, and $\overline{x_{i}}$ and $\sigma_{i}$ are the mean and SD, respectively, of the reference period.
Table 2. Winter rainfall data series in Spain for 1912-2000

\begin{tabular}{|c|c|c|c|c|c|}
\hline $\begin{array}{l}\text { Station } \\
\text { (CODE) }\end{array}$ & $\begin{array}{l}\text { Altitude } \\
\text { (m a.s.l.) }\end{array}$ & $\begin{array}{l}\text { Lati- } \\
\text { tude }\end{array}$ & $\begin{array}{l}\text { Longi- } \\
\text { tude }\end{array}$ & $\begin{array}{l}\text { Mean } \\
(\mathrm{mm})\end{array}$ & $\begin{array}{l}\mathrm{SD} \\
(\mathrm{mm})\end{array}$ \\
\hline Albacete (AB) & 7043 & $38^{\circ} 57^{\prime} \mathrm{N}$ & $01^{\circ} 51^{\prime} \mathrm{W}$ & 75.5 & 33.0 \\
\hline Almeria (AL) & 213 & $36^{\circ} 50^{\prime} \mathrm{N}$ & $02^{\circ} 23^{\prime} \mathrm{W}$ & 74.5 & 41.0 \\
\hline Alicante (A) & 823 & $38^{\circ} 22^{\prime} \mathrm{N}$ & $00^{\circ} 29^{\prime} \mathrm{W}$ & 72.7 & 48.4 \\
\hline Badajoz (BA) & 1923 & $38^{\circ} 53^{\prime} \mathrm{N}$ & $06^{\circ} 48^{\prime} \mathrm{W}$ & 166.7 & 87.4 \\
\hline Barcelona (B) & 62 & $41^{\circ} 17^{\prime} \mathrm{N}$ & $02^{\circ} 04^{\prime} \mathrm{E}$ & 126.3 & 86.0 \\
\hline Burgos (BU) & $881<$ & $42^{\circ} 21^{\prime} \mathrm{N}$ & $03^{\circ} 36^{\prime} \mathrm{W}$ & 140.0 & 65.0 \\
\hline Caceres (CC) & 4593 & $39^{\circ} 28^{\prime} \mathrm{N}$ & $06^{\circ} 20^{\prime} \mathrm{W}$ & 182.3 & 100.1 \\
\hline Ciudad Real (CR) & 629 & $38^{\circ} 59^{\prime} \mathrm{N}$ & $03^{\circ} 55^{\prime} \mathrm{W}$ & 127.8 & 74.2 \\
\hline Cuenca (CU) & $956<$ & $40^{\circ} 04^{\prime} \mathrm{N}$ & $02^{\circ} 08^{\prime} \mathrm{W}$ & 145.4 & 74.2 \\
\hline Granada (GR) & 6803 & $37^{\circ} 08^{\prime} \mathrm{N}$ & $03^{\circ} 37^{\prime} \mathrm{W}$ & 138.2 & 68.3 \\
\hline Huelva $(\mathrm{H})$ & 263 & $37^{\circ} 15^{\prime} \mathrm{N}$ & $06^{\circ} 56^{\prime} \mathrm{W}$ & 118.2 & 61.1 \\
\hline Huesca (HU) & 542 & $42^{\circ} 05^{\prime} \mathrm{N}$ & $00^{\circ} 19^{\prime} \mathrm{W}$ & 197.3 & 114.0 \\
\hline Jaen (J) & 5103 & $37^{\circ} 46^{\prime} \mathrm{N}$ & $03^{\circ} 47^{\prime} \mathrm{W}$ & 212.8 & 117.3 \\
\hline La Coruña (LC) & 672 & $43^{\circ} 22^{\prime} \mathrm{N}$ & $08^{\circ} 25^{\prime} \mathrm{W}$ & 336.3 & 127.8 \\
\hline Logroño (LO) & $352<$ & $42^{\circ} 27^{\prime} \mathrm{N}$ & $02^{\circ} 14^{\prime} \mathrm{W}$ & 92.2 & 40.3 \\
\hline Madrid (M) & $667<$ & $40^{\circ} 24^{\prime} \mathrm{N}$ & $03^{\circ} 40^{\prime} \mathrm{W}$ & 124.4 & 66.2 \\
\hline Malaga (MA) & 73 & $36^{\circ} 40^{\prime} \mathrm{N}$ & $04^{\circ} 29^{\prime} \mathrm{W}$ & 216.7 & 142.1 \\
\hline Murcia (MU) & 753 & $37^{\circ} 57^{\prime} \mathrm{N}$ & $01^{\circ} 13^{\prime} \mathrm{W}$ & 68.6 & 44.8 \\
\hline Pamplona (P) & 461 & $42^{\circ} 45^{\prime} \mathrm{N}$ & $01^{\circ} 38^{\prime} \mathrm{W}$ & 251.9 & 148.9 \\
\hline Salamanca (SA) & $790<$ & $40^{\circ} 56^{\prime} \mathrm{N}$ & $05^{\circ} 29^{\prime} \mathrm{W}$ & 110.7 & 54.0 \\
\hline S. Fernando (SF) & 303 & $36^{\circ} 27^{\prime} \mathrm{N}$ & $06^{\circ} 12^{\prime} \mathrm{W}$ & 232.4 & 117.9 \\
\hline S. Sebastian (SS) & 259 & $43^{\circ} 18^{\prime} \mathrm{N}$ & $02^{\circ} 02^{\prime} \mathrm{W}$ & 420.9 & 162.3 \\
\hline Santander (S) & 652 & $43^{\circ} 27^{\prime} \mathrm{N}$ & $03^{\circ} 49^{\prime} \mathrm{W}$ & 341.0 & 118.9 \\
\hline Santiago (SC) & 367 & $42^{\circ} 53^{\prime} \mathrm{N}$ & $08^{\circ} 25^{\prime} \mathrm{W}$ & 631.1 & 330.3 \\
\hline Segovia (SG) & 1005 & $40^{\circ} 57^{\prime} \mathrm{N}$ & $04^{\circ} 07^{\prime} \mathrm{W}$ & 127.0 & 56.9 \\
\hline Sevilla(SE) & 313 & $37^{\circ} 25^{\prime} \mathrm{N}$ & $05^{\circ} 53^{\prime} \mathrm{W}$ & 219.6 & 127.8 \\
\hline Soria (SO) & 1080 & $41^{\circ} 46^{\prime} \mathrm{N}$ & $02^{\circ} 29^{\prime} \mathrm{W}$ & 141.3 & 74.9 \\
\hline Toledo (TO) & 5403 & $39^{\circ} 51^{\prime} \mathrm{N}$ & $04^{\circ} 01^{\prime} \mathrm{W}$ & 104.0 & 54.3 \\
\hline Tortosa (TT) & 502 & $40^{\circ} 49^{\prime} \mathrm{N}$ & $00^{\circ} 29^{\prime} \mathrm{E}$ & 106.7 & 68.4 \\
\hline Valencia (V) & 113 & $39^{\circ} 28^{\prime} \mathrm{N}$ & $00^{\circ} 22^{\prime} \mathrm{W}$ & 105.7 & 67.7 \\
\hline Valladolid (VA) & 735 & $41^{\circ} 38^{\prime} \mathrm{N}$ & $04^{\circ} 46^{\prime} \mathrm{W}$ & 116.5 & 63.3 \\
\hline Zaragoza (Z) & $240<$ & $41^{\circ} 39^{\prime} \mathrm{N}$ & $01^{\circ} 00^{\prime} \mathrm{W}$ & 64.5 & 35.5 \\
\hline
\end{tabular}

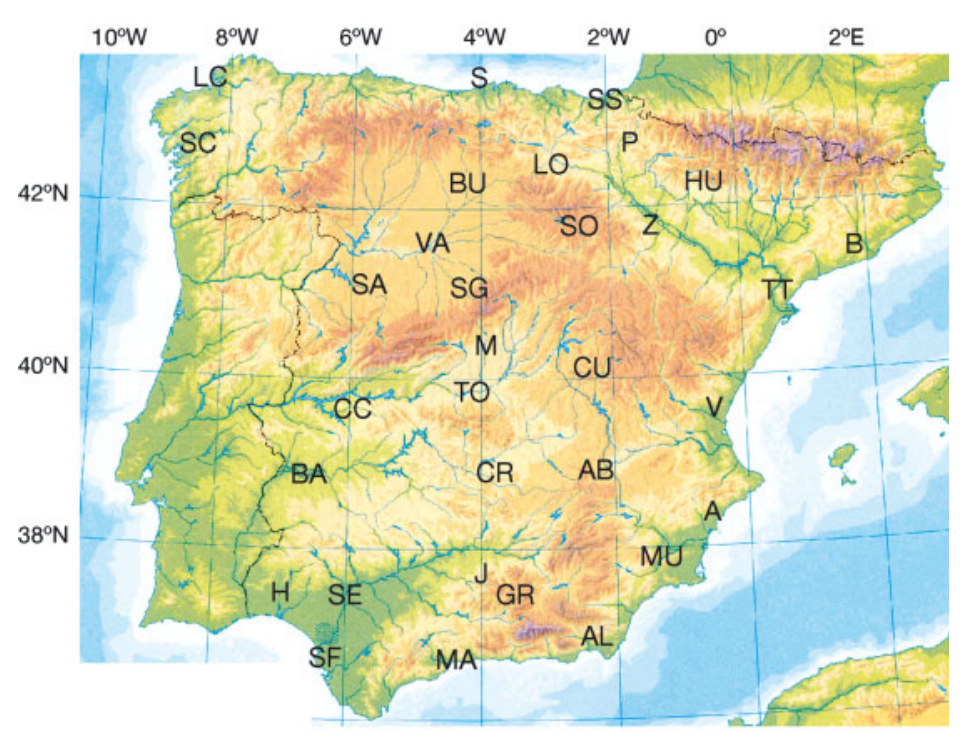

Fig. 2. Map of the study area. Rain gauges are identified by the code indicated in Table 1 


\section{ANALYSIS AND RESULTS}

\subsection{Regionalization of winter rainfall in Spain}

Cluster analysis (CA), one of the most useful data mining procedures for discovering groups and identifying patterns (Halkidi et al. 2001), was applied to reduce the dimensionality of the problem. CA is an effective statistical tool for grouping stations into climatologically homogeneous regions (DeGaetano \& Shulman 1990, Ahmed 1997, DeGaetano 2001) and for grouping time periods into clusters that reflect the occurrence of weather events or patterns (Ramos 2001). The purpose of CA is to place objects into groups not defined previously, so that objects in a given cluster suggested by the data tend to be similar to each other in some sense, and objects in different clusters tend to be dissimilar. The initial raw data consists of a $\mathrm{p} \times \mathrm{n}$ matrix $\mathbf{Z}$ that can be thought of as $\mathrm{n}$ points in a $\mathrm{p}$-dimensional space. The term 'variable' is used to denote the column vectors, and the term 'observation' is used to denote the row vectors. The most basic stage before applying a clustering algorithm is to establish a numerical similarity or dissimilarity measurement to characterize the relationships among the data. Euclidean distance is the most commonly used measure, although many other distance measurements exist (Gong \& Richman 1995). Considering a $\mathrm{p} \times \mathrm{n}$ matrix $\mathbf{Z}$ in a $\mathrm{p}$-dimensional space, the Euclidean distance $d$ between the variables $Z_{i}$ and $Z_{j}$ is given by

$$
d_{i j}=\left[\left(Z_{i}-Z_{j}\right)^{\mathrm{T}}\left(Z_{i}-Z_{j}\right)\right]^{1 / 2}
$$

where $\mathrm{T}$ is the transpose matrix, assuming that the $\mathrm{p}$ observations are independent. The range of Euclidean distance is from 0 (identical vectors or variables) to $+\infty$ (vectors without relationship).

Most common CA procedures are hierarchical (Wilks 1995). Their purpose is to form each possible number of groups $n, n-1, \ldots, 1$ in a manner that minimizes the loss of information. The first step is to combine 2 clusters $\mathrm{P}$ and $\mathrm{Q}$ whose fusion yields the least increase in the sum of squares within clusters distance from each individual to the centroid of its present cluster $n$, resulting in $n-1$ groups. The next step is to examine the $n-1$ groups to determine whether a third member should be linked with the first pair or another pairing in order to secure the optimum value of the objective function for $n-2$ groups. This process continues until all stations are clustered in 1 group and all the climatic differences are concealed (Ahmed 1997). There are various hierarchical methods, depending on the aggregation criteria. In this work, the method used is that of Ward (1963). Ward's method calculates the distance between 2 clusters as the sum of squares (SS) between the 2 clusters added up over all the variables. At each generation, the within-cluster SS is minimised over all partitions obtainable by merging 2 clusters from the previous generation. If $\mathrm{C}_{k}$ and $\mathrm{C}_{l}$ are 2 clusters merged to form cluster $\mathrm{C}_{m}$, the Euclidean distance $d$ between the new cluster and another cluster $C_{j}$ is:

$$
d_{j, m}=\frac{\left(n_{j}+n_{k}\right) d_{j k}+\left(n_{j}+n_{l}\right) d_{j l}-n_{j} d_{k l}}{n_{j}+n_{m}}
$$

where $n_{j}, n_{k}, n_{l}$ and $n_{m}$ are the number of objects in cluster $j, k, l$ and $m$, respectively, and $d_{j k}, d_{j l}$ and $d_{k}$ represent the distances between the observations in cluster $j$ and $k$, between $j$ and $l$, and between $k$ and $l$, respectively (Ramos 2001).

Although clustering results may be sensitive to the method chosen (e.g. average-linkage as opposed to Ward), Blashfield (1976, p. 387) found that Ward's method 'clearly obtained the most accurate solutions' among the 4 hierarchical methods he tested.

CA will produce a different grouping of $n$ observations at each of the $n-1$ steps. An important practical problem in CA is the choice of the intermediate step at which clusters will be formed and the number of clusters to be retained, but there are no universally accepted objective techniques by which to accomplish this (Gong \& Richman 1995). Generally this will require a subjective choice. A common subjective approach is to inspect a plot of the distances between merged clusters as a function of the stage of the analysis. When similar clusters are being merged early in the process, these distances are small, and they increase relatively little from step to step. Late in the process there may be only a few clusters, separated by large distances. If a point can be discerned where the distances between merged clusters jumps markedly, the clustering process can be stopped just before these distances become large (Wilks 1995).

Fig. 3 (top) shows the dendrogram of the standardized winter rainfall data, clustered according to the squared Euclidean distance. Fig. 3 (center) shows the distance between merged clusters as a function of the steps. Subjectively, these distances climb gradually until Stage 29 or 30, when the distances between combined clusters begin to become noticeably larger. A plausible point at which to stop the analysis is after Stage 29. This results in the definition of 3 clusters: Cluster 1 includes $68.7 \%$ of the observations, Cluster 2 has $21.9 \%$ and Cluster 3 has $9.4 \%$ (see Fig. 3, bottom). These results are similar to those of Esteban-Parra et al. (1998) and Rodriguez-Puebla et al. (1998), and they coincide with the patterns obtained by other multivariate techniques, such as principal component analysis (Muñoz-Díaz \& Rodrigo 2004). Cluster 1 is centred in western Iberia, where rainfall is mainly associated with westerly circulation (Trigo \& Palutikof 2001). Cluster 2 is associated with 

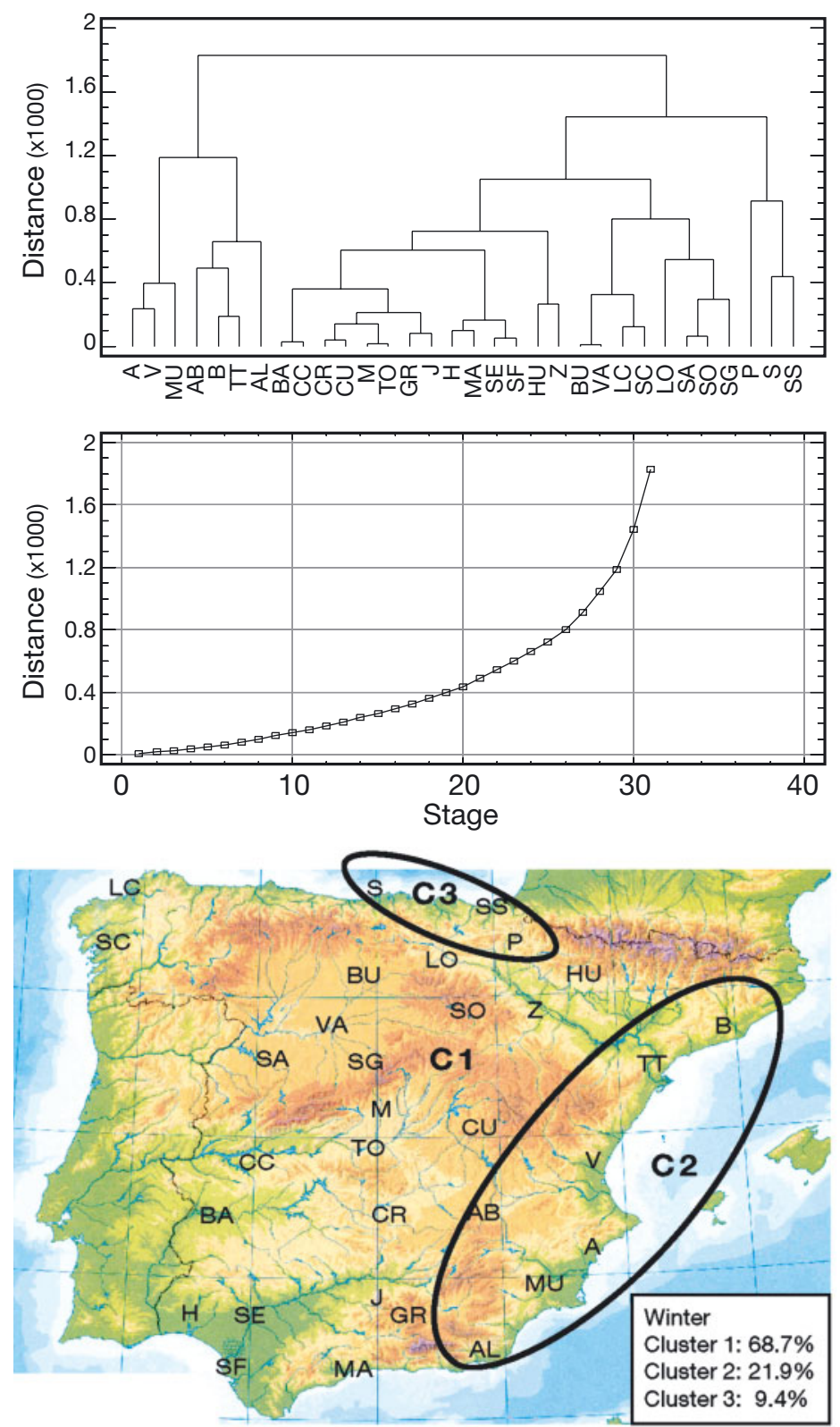

Fig. 3. Cluster analysis of the 32 stations analyzed (Ward's method, squared Euclidean distance). Top: dendrogram; Middle: agglomeration distance plot; Bottom: the 3 clusters mapped (percentage of observations corresponding to each cluster is included)

the Mediterranean coast, where precipitation is mainly produced by easterly air flows (Romero et al. 1999); this region is sheltered from the intense Atlantic disturbances by the central Spanish plateau and the Pyrenees, and also by higher land flanking the Mediterranean coast (Sumner et al. 2001). Cluster 3 is associated with the northern coast, where rainfall is mainly caused by northern or meridional fluxes (Goodess \& Jones 2002), when the blocking
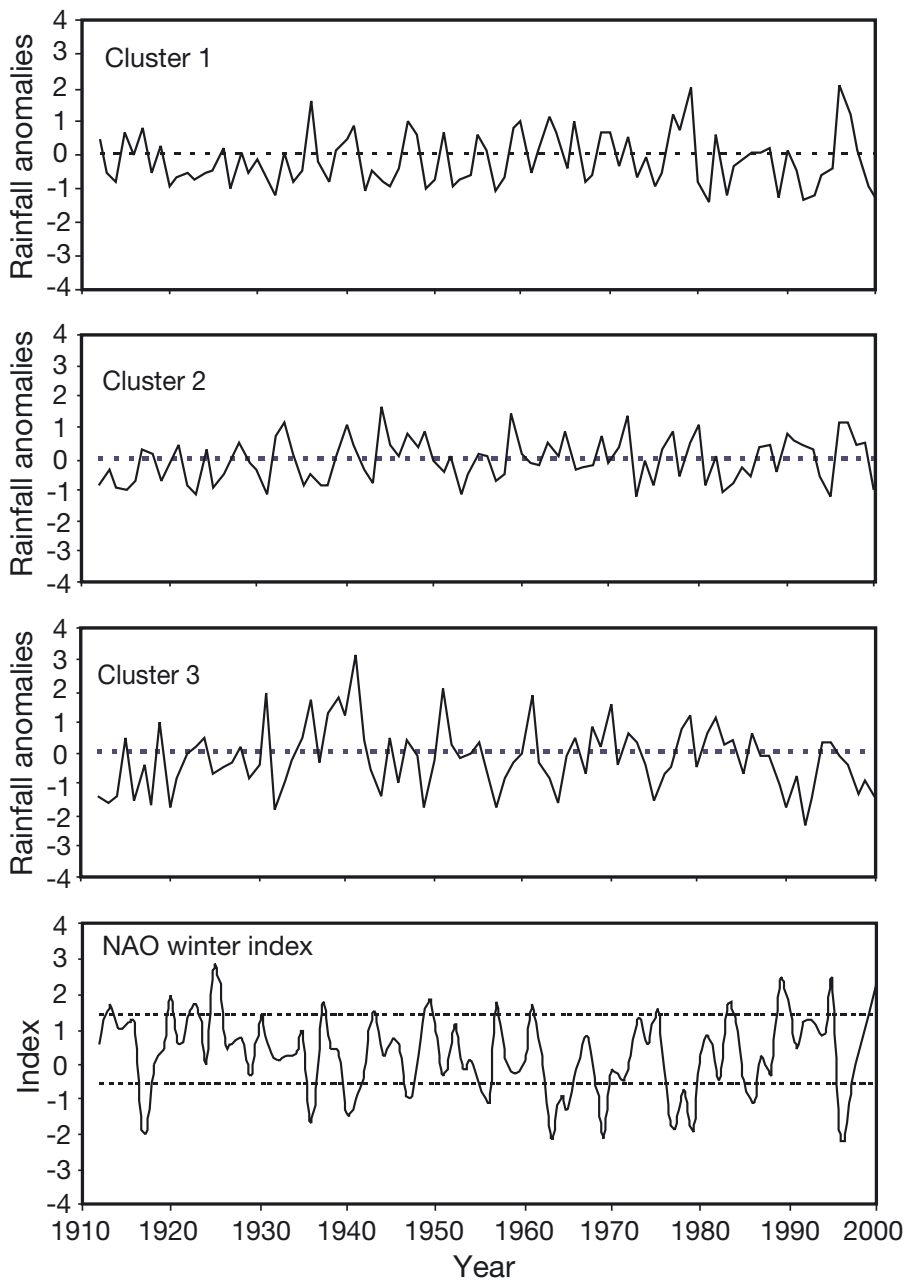

Fig. 4. Time series of rainfall anomalies corresponding to each cluster. Bottom: NAO winter index time series (threshold values determined to define NAO extreme phases are indicated by dashed lines)

effect of local orography over these fluxes forces an ascent of the air mass and precipitation in coastal or continental areas, depending on the sign of the meridional component of the fluxes (Sáenz et al. 2001). Therefore, Cluster 1 is expected to be the region mainly affected by the NAO.

Fig. 4 shows the time series of the 3 centroid series (i.e. the average for each cluster), and of the winter NAO index. Important dry periods, e.g. around 1920 for the 3 regions, or around 1990 for the western (Cluster 1) and northern (Cluster 3) regions, and wet periods, e.g. around 1960, can be detected. In general terms, rainfall anomalies and NAO show opposite behaviour, as expected. Correlation coefficients (confidence level of $95 \%$ ) between rainfall anomalies and NAO index are -0.68 for Cluster $1,-0.47$ for Cluster 2, and -0.31 for Cluster 3 , with percentages of explained variance of 46,22 and $10 \%$, respectively. 


\subsection{Changes in the probabilities of drought and abundant rainfall}

The historical impacts of the NAO on climate can be illustrated by calculating how often seasonal precipitation has been in the upper, middle and lower climatological terciles during NAO extremes. This forms sets of NAO index values $I$, used to estimate the distribution function of the rainfall anomalies series $C_{\mathrm{i}}$ conditional on these sets. A similar methodology was followed by Lucero (1998) in his analysis on the influence of El Niño-Southern Oscillation (ENSO) on rainfall in central Argentina.

Rainfall anomalies series were divided into 3 groups, corresponding to each NAO phase, for each cluster. The sets corresponding to NAO extreme phases have less data ( 17 for NAO-, and 16 for NAO+). Therefore, a theoretical distribution function for each set of rainfall anomalies was not fitted, and the study was made using the conditional empirical distribution of precipitation anomalies. Table 3 shows the parameters of the empirical distributions for the winter series corresponding to each cluster and NAO phase, and Fig. 5 shows the box plots, including the 25th and 75th percentiles of the reference period for each cluster. The mean value shifts to lower values when the NAO changes from the negative to the neutral to the positive phase. This is particularly evident in Cluster 1, where the mean changes from +0.89 to -0.31 to -0.64 (Table 4), the lower outlier for NAO- is higher than the 25th percentile of the reference period, and the median is higher than the 75 th percentile of the reference period (Fig. 5).

The distributions were, compared using a $t$-test on differences between means and an $F$-test for comparison of variances (Table 4). For Cluster 1 there is a significant difference between the mean of NAO- and NAOn, while there is no significant difference between the mean values of NAOn and NAO+, indicating asymmetry in the behavior of the series. Possibly, this is based on the slightly skewed character of the rainfall series, which implies that dry conditions typical of NAO+ are more 'normal' than wet conditions. The $F$-test indicates significant differences between vari-

Table 3. Parameters of the empirical distribution (mean NAO index $\bar{I}$ and SD), and number of data (n) for the winter series corresponding to each cluster and NAO phase

\begin{tabular}{|lcccccc|}
\hline \multirow{2}{*}{ Cluster } & \multicolumn{2}{c}{$\mathrm{NAO}-(\mathrm{n}=17)$} & \multicolumn{2}{c|}{ NAOn $(\mathrm{n}=55)$} & \multicolumn{2}{c|}{$\mathrm{NAO}+(\mathrm{n}=16)$} \\
& $\bar{I}$ & $\mathrm{SD}$ & $\bar{I}$ & $\mathrm{SD}$ & $\bar{I}$ & $\mathrm{SD}$ \\
\hline 1 & 0.89 & 0.66 & -0.31 & 0.64 & -0.64 & 0.40 \\
2 & 0.40 & 0.60 & -0.04 & 0.69 & -0.52 & 0.64 \\
3 & 0.31 & 1.11 & -0.16 & 0.97 & -0.68 & 1.06 \\
\hline
\end{tabular}
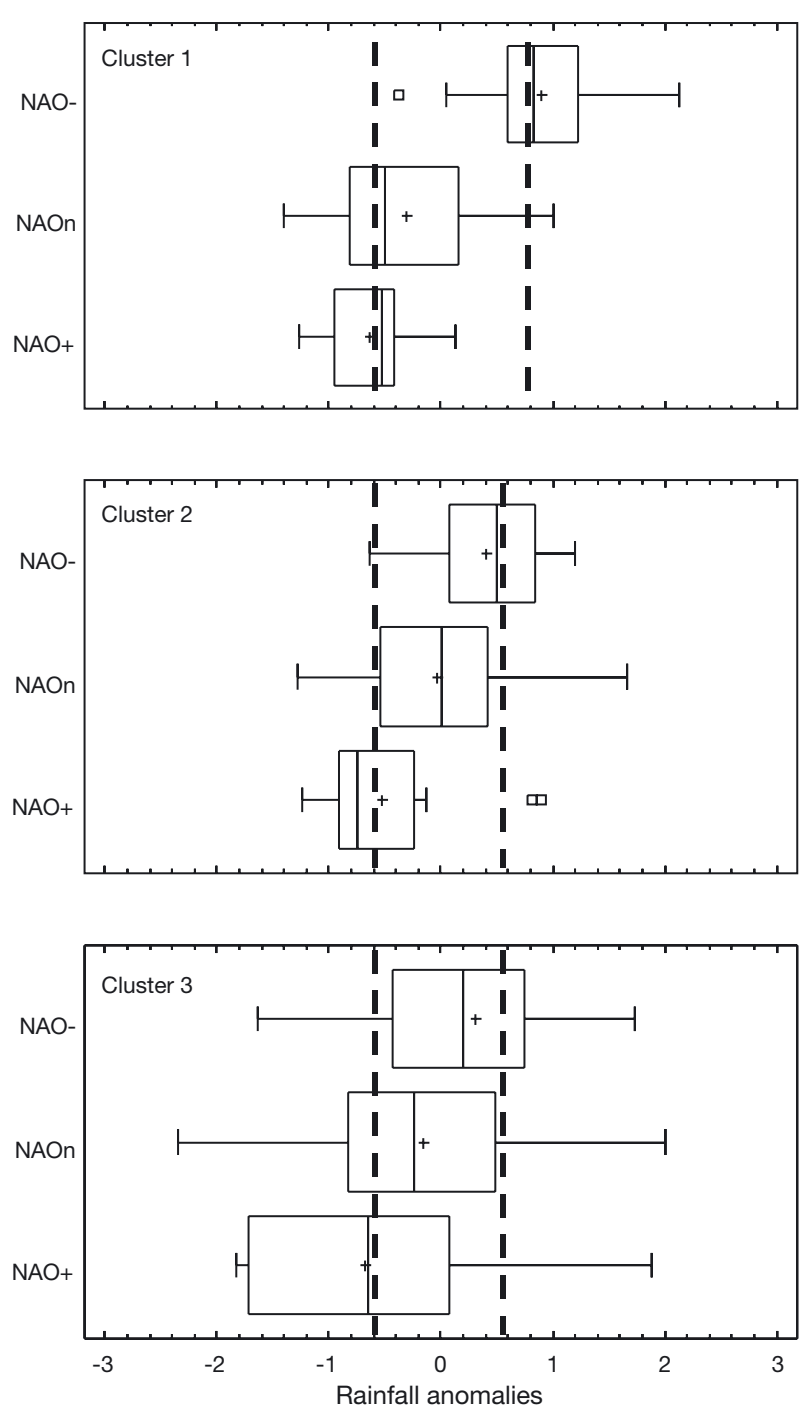

Fig. 5. Box plot of the empirical distributions of rainfall in each cluster and NAO phase for 1912-2000. Box shows the quartiles of the data; +: mean; vertical line in box: median; horizontal lines: 1.5 interquartile range; small squares: outliers; vertical dashed lines: quartiles of the reference period 1961-1990

Table 4. Comparison between the means ( $t$-test) and variances ( $F$-test) of the empirical distributions obtained for each cluster and NAO phase; ${ }^{*}$ significant at $95 \%$ confidence level

\begin{tabular}{|c|c|c|c|}
\hline & & $t$ & $F$ \\
\hline Cluster 1 & $\begin{array}{l}\mathrm{C}_{1 \mathrm{NAO}-\text { vs }} \mathrm{C}_{1 \mathrm{NAOn}} \\
\mathrm{C}_{1 \mathrm{NAOn}} \text { vs } \mathrm{C}_{1 \mathrm{NAO}+} \\
\mathrm{C}_{1 \mathrm{NAO}-\text { vs }} \mathrm{C}_{1 \mathrm{NAO}+}\end{array}$ & $\begin{array}{l}6.73^{*} \\
1.98 \\
8.00^{*}\end{array}$ & $\begin{array}{l}1.09 \\
2.57^{*} \\
2.79^{*}\end{array}$ \\
\hline Cluster 2 & $\begin{array}{l}\mathrm{C}_{2 \text { NAO- vs }} \mathrm{C}_{2 \text { NAOn }} \\
\mathrm{C}_{2 \text { NAOn Vs } \mathrm{C}_{2 \text { NAO+ }}} \\
\mathrm{C}_{2 \text { NAO- }} \text { vs } \mathrm{C}_{2 \text { NAO+ }}\end{array}$ & $\begin{array}{l}2.39^{*} \\
2.49^{*} \\
4.29^{*}\end{array}$ & $\begin{array}{l}1.32 \\
1.17 \\
1.14\end{array}$ \\
\hline Cluster 3 & $\begin{array}{l}\mathrm{C}_{3 \mathrm{NAO}} \text { vs } \mathrm{C}_{3 \mathrm{NAOn}} \\
\mathrm{C}_{3 \mathrm{NAOn}} \text { vs } \mathrm{C}_{3 \mathrm{NAO+}} \\
\mathrm{C}_{3 \mathrm{NAO}-\text { vs }} \mathrm{C}_{3 \mathrm{NAO}+}\end{array}$ & $\begin{array}{l}1.67 \\
1.86 \\
2.62^{*}\end{array}$ & $\begin{array}{l}1.31 \\
1.19 \\
1.10\end{array}$ \\
\hline
\end{tabular}


ances of NAOn and NAO+, with a higher SD in NAOn, when higher variability is expected if we compare with the dry character associated to NAO+. Regarding the similar SD values in the NAOn and NAO+ sets (Table 1), we must reject the possibility that these differences merely reflect the variability of the NAO index itself. Therefore, for Cluster 1, the change in NAO phase leads to a change in mean rainfall quantity when comparing NAO- and NAOn, and a change in rainfall variability when comparing NAOn and NAO+. Comparison of NAO- and NAO+ shows significant differences in rainfall amount between in all the 3 areas, but mainly in Cluster 1 (Table 4).

The influence of changes in the NAO on extreme rainfall events was assessed by investigating changes in the probability density functions. In the current debate on global warming, there is increasing awareness that shifts in climatic extremes are likely to have greater impact on environmental and socioeconomic systems than changes in means (Beniston \& Jungo 2002). Small changes in mean climate variables can result in large changes in both the frequency and intensity of extreme events, due to the nonlinear relationships between means and extremes (Mearns et al. 1984, Wigley 1985). In addition, changes in the variance may occur and either complement or countervail the influence of mean changes on extremes (Katz \& Brown 1992). In this study, the probabilities of dry and wet winters were computed from the empirical distributions for each series by classifying rainfall series according to the NAO phases. For each cluster, the threshold values chosen to define rainfall categories are the 25th and 75th percentiles for the reference period 1961-1990 (Table 5). Table 6 shows the proba-

Table 5. 25th and 75th percentiles of the rainfall anomalies series for the reference period 1961-1990

\begin{tabular}{|ccc|}
\hline Cluster & 25 th & 75th \\
\hline 1 & -0.59 & 0.66 \\
2 & -0.46 & 0.50 \\
3 & -0.63 & 0.63 \\
\hline
\end{tabular}

Table 6. Empirical probability $(\%)$ of dry $(z<$ P25) and wet $(z>$ P75) winters in the 3 clusters for each NAO phase during 1912-2000. Threshold values are the 25th and 75th percentiles of the reference period 1961-1990

\begin{tabular}{|lcccccc|}
\hline \multirow{2}{*}{ Cluster } & \multicolumn{2}{c}{ NAO- } & \multicolumn{2}{c}{ NAOn } & \multicolumn{2}{c|}{ NAO+ } \\
& Dry & Wet & Dry & Wet & Dry & Wet \\
\hline 1 & 0.0 & 70.6 & 43.6 & 10.9 & 43.8 & 0.0 \\
2 & 17.6 & 47.1 & 29.1 & 16.4 & 62.5 & 12.5 \\
3 & 11.8 & 35.3 & 32.7 & 18.2 & 50.0 & 6.3 \\
\hline
\end{tabular}

bility of dry ( $z<$ P25) and wet $(z>$ P75) winters for each cluster and NAO phase during 1912-2000. For Cluster 1 , the probability of droughts is $0.0 \%$ during NAO-, $43.6 \%$ during NAOn, and $43.8 \%$ during NAO+, and the probability of abundant rainfall is $70.6 \%$ during NAO-, $10.9 \%$ during NAOn, and $0.0 \%$ during NAO+. This inverse relationship is also evident for Clusters 2 and 3.

The influence of NAO- on the probability of abundant rainfall is higher for Cluster 1 than for Clusters 2 and 3, whereas the probability of drought is higher for Clusters 2 and 3, and for NAO+ (Table 6). A possibly explanation is that the Mediterranean Cluster 2 and the northern Cluster 3 are sheltered by mountains from westerly flows associated with NAO- (Romero et al. 1998), while anticyclonic activity associated with $\mathrm{NAO}+$ affects the whole peninsula.

For Cluster 1, the probability of wet winters for $\mathrm{NAO}$ - is higher than the probability of dry winters for $\mathrm{NAO}+$ (Table 6). This demonstrates that winter rainfall in the study area does not vary in a linear way with respect to the phase and intensity of the NAO. Similar differences in extremes under NAO+ and NAO- were found by Pozo-Vázquez et al. (2001) in their analysis of the influence of NAO on surface temperatures in central Europe and the Iberian Peninsula, and by Wettstein \& Mearns (2002) in their study on the influence of NAO on temperatures in NE USA and Canada. $\mathrm{NAO}$ is not the only circulation regime that influences rainfall, and Yiou \& Nogaj (2004) underline the role of the Scandinavian blocking regime, which controls the drought periods across the NW North Atlantic and eastern Scandinavia, while heavy precipitation is caused by NAO+ in the same area. Further research is needed to confirm such non-linearity. For Clusters 2 and 3, the probability of dry winters during NAO+ is higher than the probability of wet winters during NAO- (Table 6), indicating that these areas are more influenced by NAO+ than by NAO-.

\section{CONCLUSIONS}

The methodology of conditional probabilities adopted in this study yields results suggesting that the NAO phase does not simply increase or decrease rainfall, but also affects the probabilities of extreme rainfall and modifies the spatial distribution of its impacts. Although the predictive skill of the method remains to be evaluated, the main result of this study is the quantification of the climate risks and their potential prediction:

(1) For the western Iberian Peninsula (Cluster 1) a change from NAOn to NAO-implies a change in mean winter rainfall, and a change from NAOn to NAO+ implies a change in variance. For the Mediterranean 
area (Cluster 2) NAO phase changes imply changes in mean winter rainfall, but no significant changes in variance. For the northern area (Cluster 3) there are no significant changes.

(2) These changes provoke non-linear responses in probabilities of extreme conditions. These conditions have been defined as drought when rainfall anomalies are $<25$ th percentile, and abundant rainfall when rainfall anomalies are $>75$ th percentile of the reference period 1961-1990.

(3) The inverse relationship between NAO phases and rainfall in Spain is confirmed.

(4) The influence of NAO- is higher for the western area (Cluster 1) than for the Mediterranean and northern areas (Clusters 2 and 3). However, the influence of $\mathrm{NAO}+$ on the probability of drought is similar for the 3 regions ( $>40 \%)$.

(5) A slight asymmetry is detected, with higher probabilities of abundant rainfall during NAO- than of drought during NAO+ for the western area (Cluster 1). On the other hand, Clusters 2 and 3 show higher probability of drought during $\mathrm{NAO}+$ than of abundant rainfall during NAO-.

Meanwhile NAO+ seems influence on the whole country, with similar dry conditions in the 3 areas, NAO- phase impacts are more important for the western area of the country. These results are in good agreement with other results previously reported (Esteban-Parra et al. 1998, Goodess \& Jones 2002, MuñozDíaz \& Rodrigo 2003), and, in addition, allow estimate quantitatively the probability of climate risks associated to NAO phases in the study area. If the NAO can be predicted, it may allow the estimation of winter rainfall anomalies a few months in advance. The combined use of these climate prediction analysis and our results may be of interest for planning agricultural and water management activities. Probabilities shown in Table 6 may be used by users by incorporating their own cost and loss information, to calculate the expected expense for a range of threshold values, in the sense described, for instance, by Palmer et al. (2000).

Although NAO exerts a strong influence on temperature and precipitation throughout much of Europe, mainly during winter, the analysis can be extended to the other seasons of the year. This is the objective of a study now in preparation. Preliminary analysis shows similar results; e.g. for a region similar to winter Cluster 1, the probability of a wet spring during NAOis $75 \%$ and the probability of a dry spring during $\mathrm{NAO}+$ is $32.5 \%$, and in autumn these percentages are $49 \%$ and $28 \%$, respectively.

Other teleconnections, such as ENSO, may affect rainfall regime in the Iberian Peninsula. According to Rodó et al. (1977), the percentage of springtime variability due to ENSO in the eastern part of Spain is around 50\%. Rocha (1999) also found a significant association between ENSO and rainfall, particularly over the SE Iberian Peninsula, with negative anomalies in spring rainfall and above-average rainfall in the autumn following a year of ENSO onset. The application of the methodology developed in this study to the relationship between ENSO and Spanish rainfall is the objective of another study now in preparation.

Acknowledgments. The Spanish CICYT REN2001-3923-C02$02 / C L I$ project has financed this study. The authors are grateful to the anonymous referees for their useful comments.

\section{LITERATURE CITED}

Ahmed BYM (1997) Climatic classification of Saudi Arabia: an application of factor-cluster analysis. GeoJournal 41:69-84

Almarza C, López JA, Flores C (1996) Homogeneidad y variabilidad de los registros históricos de precipitación en España. Instituto Nacional de Meteorología, Madrid, 318 p

Baldwin MP, Stephenson DB, Thompson DWJ, Dunkerton TJ, Charlton AJ, O'Neill A (2003) Stratospheric memory and skill of extended-range weather forecasts. Science 301: $636-640$

Barnston, AG, Livezey RE (1987) Classification, seasonality and persistence of low-frequency atmospheric circulation patterns. Mon Weather Rev 115:1083-1126

Beniston M, Jungo P (2002) Shifts in the distribution of pressure, temperature and moisture and changes in the typical weather patterns in the alpine region in response to the behavior of the North Atlantic Oscillation. Theor Appl Climatol 71:29-42

Blashfield RK (1976) Mixture model tests of cluster analysis: accuracy of four agglomerative hierarchical methods. Psychol Bull 83:377-388

Bodri L, Cermak V (2003) High frequency variability in recent climate and the North Atlantic Oscillation. Theor Appl Climatol 74:33-40

Burgers G, Stephenson DB (1999) The 'normality' of El Niño. Geophys Res Lett 26:1027-1030

Corte-Real J, Quian B, Xu H (1998) Regional climate change in Portugal: precipitation variability associated with largescale atmospheric circulation. Int J Climatol 18:619-635

Dai AK, Trenberth E, Karl TR (1998) Global variations in droughts and wet spells: 1990-1995. Geophys Res Lett 25:3367-3370

DeGaetano AT (2001) Spatial grouping of United States climates stations using a hybrid clustering approach. Int $\mathrm{J}$ Climatol 21:791-807

DeGaetano AT, Shulman MD (1990) A climatic classification of plant hardiness in the United States and Canada. Agric For Meteorol 51:333-351

Esteban-Parra MJ, Rodrigo FS, Castro-Díez Y (1998) Spatial and temporal patterns of precipitation in Spain for the period 1880-1992. Int J Climatol 18:1557-1574

Esteves MA, Orgaz MDM (2001) The influence of climatic variability on the quality of wine. Int J Biometeorol 45:13-21

Fowler HJ, Kilsby CG (2002) Precipitation and the North Atlantic Oscillation: a study of climatic variability in northern England. Int J Climatol 22:843-866

Gong X, Richman MB (1995) On the application of cluster analysis to growing season precipitation data in North America East of the Rockies. J Clim 8:897-931 
Goodess C, Jones PD (2002) Links between circulation and changes in the characteristics of Iberian rainfall. Int J Climatol 22:1593-1615

Halkidi M, Batistakis Y, Vazirgiannis M (2001) On clustering validation techniques. J Intellig Inf Syst 17:107-145

Hulme M, Sheard N (1999) Escenarios de cambio climático para la Península Ibérica. Climate Research Unit, University of East Anglia, $6 \mathrm{p}$

Hurrell JW (1995) Decadal trends in the North Atlantic Oscillation and relationship to regional temperatures and precipitation. Science 269:676-679

Hurrell JW, van Loon H (1997) Decadal variations in climate associated with the North Atlantic Oscillation. Clim Change 36:301-326

Hurrell JW, Kushnir Y, Ottersen G, Visbeck M (2003) An overview of the North Atlantic Oscillation. In: Hurrell JW, Kushnir Y, Ottersen G, Visbeck M (eds) The North Atlantic Oscillation: climatic significance and environmental impact. American Geophysical Union, Washington, $\mathrm{DC}, 1-35$

Jones PD, Jónsson T, Wheeler D (1997) Extension to the North Atlantic Oscillation using early instrumental pressure observations from Gibraltar and South-West Iceland. Int J Climatol 17:1433-1450

Jones PD, Osborn TJ, Briffa KR (2003) Pressure-based measures of the North Atlantic Oscillation (NAO): a comparison and an assessment of changes in the strength of the NAO and its influence on surface climate parameters. In: Hurrell JW, Kushnir Y, Ottersen G, Visbeck M (eds) The North Atlantic Oscillation: climatic significance and environmental impact. American Geophysical Union, Washington, DC, 51-62

Katz RW, Brown BG (1992) Extreme events in a changing climate: variability is more important than averages. Clim Change 21:289-302

Kettlewell PS, Sothern RB, Koukkari WL (1999) U.K. wheat quality and economic value are dependent on the North Atlantic Oscillation. J Cereal Sci 29:205-209

Kettlewell PS, Stephenson DB, Atkinson MD, Hollins PD (2003) Summer rainfall and wheat grain quality: relationships with the North Atlantic Oscillation. Weather 58: 155-164

Knippertz P, Christoph M, Speth P (2003) Long-term precipitation variability in Morocco and the link to the large-scale circulation in recent and future climates. Meteorol Atmos Phys 83:67-88

Lamb PJ, Peppler RA (1987) North Atlantic Oscillation, concept and application. Bull Am Meteorol Soc 68:1218-1225

Lucero OA (1998) Effects of the southern oscillation on the probability for climatic categories of monthly rainfall, in a semi-arid region in the southern mid-latitudes. Atmos Res 49:337-348

Matyasovszky I (2003) High frequency variability in recent climate and the North Atlantic Oscillation. Theor Appl Climatol 74:69-75

Mearns LO, Katz RW, Schneider SH (1984) Extreme hightemperature events: changes in their probabilities with changes in mean temperature. J Clim Appl Meteorol 23:1601-1613

Muñoz-Díaz D, Rodrigo FS (2003) Effects of the North Atlantic Oscillation on the probability for climatic categories of local monthly rainfall in southern Spain. Int J Climatol 23:381-397

Muñoz-Díaz D, Rodrigo FS (2004) Spatio-temporal patterns of seasonal rainfall in Spain (1912-2000) using cluster and principal component analysis: comparison. Ann Geophys 22:1435-1448
Murphy SJ, Washington R (2001) United Kingdom and Ireland precipitation variability and the North Atlantic sea-level pressure field. Int J Climatol 21:939-959

Mysterud A, Stenseth NC, Yoccoz NG, Ottersen G, Langvatn $\mathrm{R}$ (2003) The response of terrestrial ecosystems to climate variability associated with the North Atlantic Oscillation. In: Hurrell JW, Kushnir Y, Ottersen G, Visbeck M (eds) The North Atlantic Oscillation: climatic significance and environmental impact. American Geophysical Union, Washington, DC, 235-262

Ojo SO, Afiesimama EA (2000) Uso de promedios de periodos de referencia para examinar anomalías del clima. WMO, Boletín de la Organización Meteorológica Mundial 49: 288-291

Palmer TN, Brankovic C, Richardson DS (2000) A probability and decision model analysis of PROVOST seasonal multimodel ensemble integrations. Quart J Roy Meteorol Soc 126:2013-2033

Peña-Sánchez D (1995) Estadística. Modelos y métodos. Alianza Universitaria, Madrid, $427 \mathrm{p}$

Pozo-Vázquez D, Esteban-Parra MJ, Rodrigo FS, Castro-Díez Y (2000) An analysis of the variability of the North Atlantic Oscillation in the time and frequency domains. Int $\mathrm{J}$ Climatol 20:1675-1692

Pozo-Vázquez D, Esteban-Parra MJ, Rodrigo FS, Castro-Díez Y (2001) A study of NAO variability and its posible nonlinear influence on European surface temperature. Clim Dynam 17:701-715

Ramos MC (2001) Divisive and hierarchical clustering techniques to analyse variability of rainfall distribution patterns in a Mediterranean region. Atmos Res 57:123-138

Rîmbu N, Boroneant C, Buta C, Dima M (2002) Decadal variability of the Danube river flow in the lower basin and its relation with the North Atlantic Oscillation. Int J Climatol 22:1169-1179

Rocha A (1999) Low-frequency variability of seasonal rainfall over the Iberian Peninsula and ENSO. Int J Climatol 19:889-901

Rodó X, Comín FA (2000) Links between large-scale anomalies, rainfall and wine quality in the Iberian Peninsula during the last three decades. Global Change Biol 6: $267-273$

Rodó X, Baert E, Comín FA (1977) Variations in seasonal rainfall in southern Europe during the present century: relationships with the North Atlantic Oscillation and the El Niño-Southern Oscillation. Clim Dyn 13:275-284

Rodríguez-Puebla CA, Encinas H, Nieto S, Garmendia J (1998) Spatial and temporal patterns of annual precipitation variability over the Iberian Peninsula. Int J Climatol 18:299-316

Rodwell MJ (2003) On the predictability of North Atlantic climate. In: Hurrell JW, Kushnir Y, Ottersen G, Visbeck M (eds) The North Atlantic Oscillation: climatic significance and environmental impact. American Geophysical Union, Washington, DC, 173-192

Rodwell MJ, Folland CK (2001) Atlantic air-sea interaction and seasonal predictability. Quart J Roy Meteorol Soc 128:1413-1443

Rogers JC, van Loon H (1979) The seesaw in winter temperatures between Greenland and the southern oscillation in the Northern Hemisphere. Mon Weather Rev 107:509-519

Romero R, Guijarro JA, Ramis C, Alonso S (1998) A 30 years (1964-1993) daily rainfall data base for the Spanish Mediterranean regions: first exploratory study. Int J Climatol 18:541-560

Romero R, Sumner G, Ramis C, Genovés A (1999) A classification of the atmospheric circulation in patterns producing 
significant daily rainfall in the Spanish Mediterranean area. Int J Climatol 19:765-785

Sáenz J, Zubillaga J, Rodríguez-Puebla C (2001) Interanual variability of winter precipitation in Northern Iberian Peninsula. Int J Climatol 21:1503-1513

Saunders MA, Qian B, Lloyd-Hughes B (2003) Summer snow extent heralding of the winter North Atlantic Oscillation. Geophys Res Lett 30(7), 1378, doi: 10.129/2002GL016832

Sumner G, Homar V, Ramis C (2001) Precipitation seasonality in eastern and southern coastal Spain. Int J Climatol 21: 219-247

Trigo RM, Palutikof JP (2001) Precipitation scenarios over Iberia: a comparison between direct GCM output and different downscaling techniques. J Clim 14:4422-4446

Trigo RM, Osborn TJ, Corte-Real JM (2002) The North Atlantic Oscillation influence on Europe: climate impacts and associated physical mechanisms. Clim Res 20:9-17

Ulbrich U, Christpoh M, Pinto JG, Corte-Real J (1999) Dependence of winter precipitation over Portugal on NAO and baroclinic wave activity. Int J Climatol 19:379-390

Uvo CB (2003) Analysis and regionalization of Northern European winter precipitation based on its relationship with the North Atlantic Oscillation. Int $\mathrm{J}$ Climatol 23:1185-1194

Editorial responsibility: Otto Kinne, Oldendorf/Luhe, Germany
Wanner H, Brönnimann S, Casty C, Gyalistras D, Luterbacher J, Schmutz C, Stephenson DB, Xoplaki E (2001) Borth Atlantic Oscillation - concepts and studies. Surv Geophys 22:321-382

Ward JH (1963) Hierarchical grouping to optimise an objective function. J Amer Stat Assoc 58:236-244

Wettstein JJ, Mearns LO (2002) The influence of the North Atlantic/Artic Oscillation on mean, variance and extremes of temperature in the Northeastern United States and Canada. J Clim 15:3586-3600

Wigley TML (1985) Impact of extreme events. Nature 316: 106-107

Wilby RL (2001) Seasonal forescasting of river flows in the British Isles using North Atlantic pressure patterns. J Chartered Instit Wat Env Manage 15:56-63

Wilks DS (1995) Statistical methods in the atmospheric sciences. Academic Press, San Diego, $467 \mathrm{p}$

Yiou P, Nogaj M (2004) Extreme climatic events and westher regimes over the North Atlantic: when and where? Geophys Res Lett 31: L07202, doi: 10.129/2003GL019119

Zorita E, Kharin V, von Storch H (1992) The atmospheric circulation and sea surface temperature in the North Atlantic area in winter: their interaction and relevance for Iberian precipitation. J Clim 5:1097-1108

Submitted: February 4, 2004; Accepted: May 27, 2004 Proofs received from author(s): July 1, 2004 